\title{
Effect of Addition of Phosphate Powder on Unconfined Compressive Strength of Sand Cemented with Calcium Phosphate Compound
}

\author{
Satoru Kawasaki ${ }^{1, *}$ and Masaru Akiyama ${ }^{2}$ \\ ${ }^{1}$ Faculty of Engineering, Hokkaido University, Sapporo 060-8628, Japan \\ ${ }^{2}$ Geoscience Research Laboratory Co., Ltd., Yamato 242-0014, Japan
}

For the purpose of improving a novel grout composed of a calcium phosphate compound (CPC-Chem), we have conducted an unconfined compressive strength (UCS) test on samples cemented with CPC-Chem and tricalcium phosphate (TCP) powder. The UCS of these test samples was significantly larger than the UCS of the non-additive test samples. The UCS reached the targeted value of over $100 \mathrm{kPa}$, and after $28 \mathrm{days}$ of curing, reached a maximum of $261.4 \mathrm{kPa}$. Additionally, the $\mathrm{pH}$ of the samples cemented with CPC-Chem and TCP powder was weakly acidic. These results suggest that the novel geotechnical method using a combination of CPC-Chem and TCP powder has the potential to be used as a non-contaminating and recyclable application, as a biogrout that uses microbial activity and for ground improvement because it satisfies the strength requirements for practical use. [doi:10.2320/matertrans.M-M2013827]

(Received July 25, 2013; Accepted July 31, 2013; Published September 13, 2013)

Keywords: ground improvement, biogrout, calcium phosphate compound, unconfined compressive strength, seed crystal

\section{Introduction}

In recent years, novel grout technologies have been developed for ground reinforcement and ground permeability control with bacterially produced cement materials. ${ }^{1-9)}$ The process of ground improvement by biological action is called "biogrouting ${ }^{10)}$ ". We have developed a novel ground stabilizer ${ }^{11,12)}$ for increasing the usage options for the cement materials and the cementing mechanisms by using microorganisms (Fig. 1). Further, we have reported on a calcium phosphate compound (CPC) chemical grout (CPC-Chem) that uses self-setting CPC mechanisms (Fig. 2), and on a $\mathrm{CPC}$ biogrout (CPC-Bio) that has a microbial $\mathrm{pH}$-increasing reaction and a solubility with a $\mathrm{pH}$ dependency (Fig. 3). The unconfined compressive strength (UCS) of the sand test samples cemented with the CPC-Chem attained a maximum of $63.5 \mathrm{kPa}{ }^{11)}$ The UCS increased from 42.9 to $57.6 \mathrm{kPa}$ after using a CPC-Bio with the same composition of the CPCChem with soil microorganisms and an ammonia source. ${ }^{12)}$ We have targeted UCS values of $50-100 \mathrm{kPa},{ }^{13)}$ which are needed to avoid ground liquefaction during earthquakes, implying that both the CPC-Chem and the CPC-Bio can achieve enough strength as ground stabilizers. However, because their UCS values were obtained through laboratory tests from sand test samples that were tamped homogeneously, the strength yielded in a practical setting by the ground stabilizer is expected to improve because of its use in a complex and heterogeneous ground.

In the medical and dental sciences, the CPC paste is used for supplementing a lack of bone and teeth by using a mechanism called hydroxyapatite (HA) precipitation, ${ }^{14)}$ which is a mixing of tetracalcium phosphate (TTCP) with dicalcium phosphate (DCP). The two CPC powders appeared to play two roles during the solidification of the paste: the phosphate and calcium as sources for HA, and the seed crystal ${ }^{15-18)}$ that promotes the precipitation and growth of HA. The existing biogrout also uses bacterial cells as the nucleus of calcium carbonate precipitation. ${ }^{4)}$ The over-

*Corresponding author, E-mail: kawasaki@geo-er.eng.hokudai.ac.jp

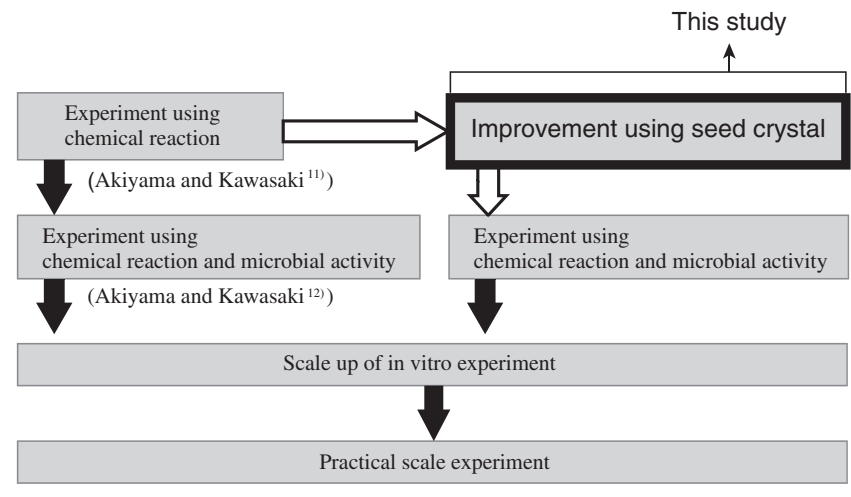

Fig. 1 Flowchart of study.

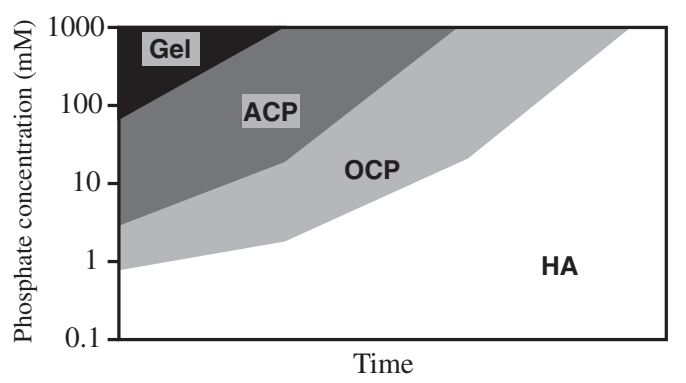

Fig. 2 Formation, stability and hydrolysis of calcium phosphates as function of phosphate concentration $(\log (\mathrm{P}))$ in solutions of amorphous calcium phosphate (ACP) at a neutral $\mathrm{pH}$. OCP - octacalcium phosphate; HA - hydroxyapatite. The figure is adapted from Tung. ${ }^{20)}$

saturated solution and the seed crystal generally coexist, yielding effective crystal growth. ${ }^{19)}$ These facts indicate that the presence of seed crystals can improve the speed and efficiency of crystal precipitation.

Therefore, we have begun to improve the CPC-Chem using tricalcium phosphate (TCP) powder, which is a type of $\mathrm{CPC}^{14)}$ (Table 1). This study aims to exceed a maximum UCS of $100 \mathrm{kPa}$ after 28 days of curing, which is the strength performance required to use the CPC-Chem and TCP powder combination as a countermeasure against ground liquefaction during earthquakes. 
Table 1 Hydrolysis of CPCs. ${ }^{20)}$

\begin{tabular}{llll}
\hline \multicolumn{1}{c}{ Compound } & $\mathrm{Ca} / \mathrm{P}$ & Abbr. & \multicolumn{1}{c}{ Formula and hydrolysis } \\
\hline Monocalcium phosphate & 0.5 & $\mathrm{MCP}$ & $5 \mathrm{Ca}\left(\mathrm{H}_{2} \mathrm{PO}_{4}\right)_{2} \cdot \mathrm{H}_{2} \mathrm{O} \rightarrow \mathrm{Ca}_{5}\left(\mathrm{PO}_{4}\right)_{3} \mathrm{OH}+7 \mathrm{H}_{3} \mathrm{PO}_{4}+4 \mathrm{H}_{2} \mathrm{O}$ \\
Dicalcium phosphate & 1.0 & $\mathrm{DCP}$ & $5 \mathrm{CaHPO}_{4}+\mathrm{H}_{2} \mathrm{O} \rightarrow \mathrm{Ca}_{5}\left(\mathrm{PO}_{4}\right)_{3} \mathrm{OH}+2 \mathrm{H}_{3} \mathrm{PO}_{4}$ \\
Octacalcium phosphate & 1.33 & OCP & $5 \mathrm{Ca}_{8}\left(\mathrm{PO}_{4}\right)_{6} \mathrm{H}_{2} \cdot 5 \mathrm{H}_{2} \mathrm{O} \rightarrow 8 \mathrm{Ca}_{5}\left(\mathrm{PO}_{4}\right)_{3} \mathrm{OH}+6 \mathrm{H}_{3} \mathrm{PO}_{4}+17 \mathrm{H}_{2} \mathrm{O}$ \\
Tricalcium phosphate & 1.5 & TCP & $5 \mathrm{Ca}_{3}\left(\mathrm{PO}_{4}\right)_{2}+3 \mathrm{H}_{2} \mathrm{O} \rightarrow 3 \mathrm{Ca}_{5}\left(\mathrm{PO}_{4}\right)_{3} \mathrm{OH}+\mathrm{H}_{3} \mathrm{PO}_{4}$ \\
Hydroxyapatite & 1.67 & $\mathrm{HA}$ & $\mathrm{Ca}_{5}\left(\mathrm{PO}_{4}\right)_{3} \mathrm{OH}$ \\
Tetracalcium phosphate & 2.0 & TTCP & $3 \mathrm{Ca}_{4}\left(\mathrm{PO}_{4}\right)_{2} \mathrm{O}+3 \mathrm{H}_{2} \mathrm{O} \rightarrow 2 \mathrm{Ca}_{5}\left(\mathrm{PO}_{4}\right)_{3} \mathrm{OH}+2 \mathrm{Ca}(\mathrm{OH})_{2}$ \\
\hline
\end{tabular}

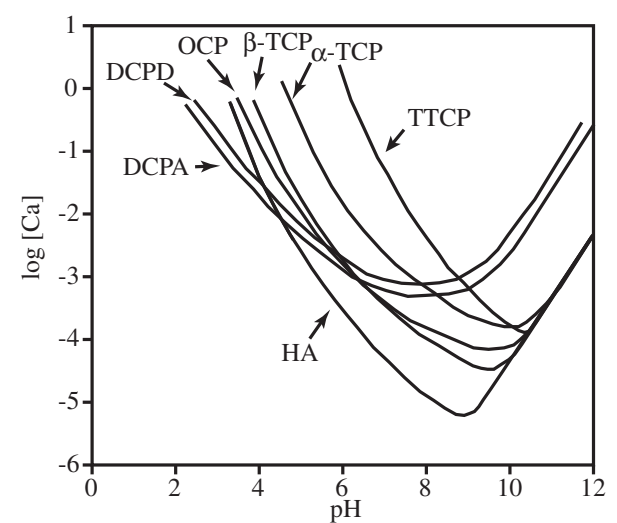

Fig. 3 Solubility phase diagrams for ternary system, $\mathrm{Ca}(\mathrm{OH})_{2}-\mathrm{H}_{3} \mathrm{PO}_{4}-$ $\mathrm{H}_{2} \mathrm{O}$, at $25^{\circ} \mathrm{C}$ showing solubility isotherms of $\mathrm{CaHPO}_{4}$ (DCPA), $\mathrm{CaHPO}_{4} \cdot 2 \mathrm{H}_{2} \mathrm{O}$ (DCPD), $\mathrm{Ca}_{8} \mathrm{H}_{2}\left(\mathrm{PO}_{4}\right)_{6} \cdot 5 \mathrm{H}_{2} \mathrm{O}(\mathrm{OCP}), \alpha-\mathrm{Ca}_{3}\left(\mathrm{PO}_{4}\right)_{2} \quad(\alpha-$ TCP), $\beta-\mathrm{Ca}_{3}\left(\mathrm{PO}_{4}\right)_{2}\left(\beta\right.$-TCP), $\mathrm{Ca}_{4}\left(\mathrm{PO}_{4}\right)_{2} \mathrm{O}$ (TTCP) and $\mathrm{Ca}_{5}\left(\mathrm{PO}_{4}\right)_{3} \mathrm{OH}$ (HA). The figure is adapted from Tung. ${ }^{20)}$

\section{Choice of CPC Powder}

In this study, we have chosen TCP (particle density $\rho=3.14 \mathrm{~g} / \mathrm{cm}^{3}$, mean diameter $D_{50}=12.0 \mu \mathrm{m}, 85 \%$ diameter $D_{85}=34.8 \mu \mathrm{m}$ ) from the various CPCs (Table 1) because of two properties it has that are expected to contribute to the increase in the UCS of the samples. First, the entire precipitation mass can be increased. Second, TCP can be solidified by a self-setting process. Although CPCs apart from TCP can transform into HA through hydrolysis, they may significantly decrease the $\mathrm{pH}$ via the release of a phosphate ion as a byproduct. ${ }^{14)}$ The low $\mathrm{pH}$ induces the dissolution of HA, resulting in a decrease in the CPC precipitation mass and therefore a decrease in the UCS. ${ }^{20)} \mathrm{We}$ have chosen TCP powder as the seed crystal, which releases the lowest amount of phosphate ions during hydrolysis. TCP possesses insolubility in the neutral to weakly alkaline $\mathrm{pH}$ range (Fig. 3), and is not vulnerable to long-term contact with water because it changes into HA over time by selfsetting. ${ }^{20)}$ TCP is an approved food additive in Japan, indicating that it is non-toxic and easy to acquire.

TTCP is also promising to use as a seed crystal because it releases calcium hydroxide during hydrolysis and does not dissolve the precipitated CPC. We have selected TCP among all the CPCs because of cost; $420 \mathrm{yen} / \mathrm{g}$ for TTCP is significantly more expensive than 5.6 yen $/ \mathrm{g}$ for $\mathrm{TCP} .^{21)}$

However, from the practical viewpoint of engineering, TCP is also not inexpensive enough for widespread use. A high-grade reagent was used to fabricate the TCP used in this study, which warrants future examination to decrease the cost of the TCP powder. Although there is little production of TCP now, the cost of TCP will decrease as the production of TCP increases in the future.

\section{Materials and Methods}

In this study, a concentration combination of phosphate solutions (diammonium phosphate, DAP) and calcium solutions (calcium nitrate, $\mathrm{CN}$, or calcium acetate, $\mathrm{CA}$ ) was used as a CPC-Chem (DAP : $\mathrm{CA}=1.5 \mathrm{M}: 0.75 \mathrm{M}$ ); this yielded the best UCS among all mixtures. ${ }^{11)} \mathrm{A}$ standard sand test sample was made from $320.09 \mathrm{~g}$ of Toyoura sand (soil particle density $\rho_{\mathrm{s}}=2.64 \mathrm{~g} / \mathrm{cm}^{3}$, minimum density $\rho_{\min }=$ $1.335 \mathrm{~g} / \mathrm{cm}^{3}$, maximum density $\rho_{\max }=1.645 \mathrm{~g} / \mathrm{cm}^{3}$, mean diameter $D_{50}=170 \mu \mathrm{m}, 15 \%$ diameter $\left.D_{15}=150 \mu \mathrm{m}\right)$ and $73.3 \mathrm{~mL}$ of CPC-Chem, following a previous report. ${ }^{11)}$ The test samples were made with the combination ratios shown in Fig. 4 and then examined. 1\% (3.2 g, TCP-01), 5\% (16.0 g, TCP-05) and $10 \%(32.0 \mathrm{~g}$, TCP-10) of TCP were added to $316.89,304.09$ and $288.09 \mathrm{~g}$ of Toyoura sand, respectively, each mixture yielding the weight of a standard sand test sample of $320.09 \mathrm{~g}$. Next, CPC-Chem was added to the Toyoura sand and TCP mixture. It was uniformly mixed in a stainless-steel ball for 2 min and divided into quarters, each of which was placed into a plastic mold container (inner diameter $\varphi=50 \mathrm{~mm}$, height $h=100 \mathrm{~mm}$ ). To avoid disturbing the sample during its removal from the mold, the inner wall of the mold was covered with a $0.1-\mathrm{mm}$-thick overhead projector sheet. After each of the four quarters was placed in the mold, the sand was tamped down 30 times by a hand rammer. Finally, the upper edge of the test sample was trimmed flat and covered with Parafilm M (Structure Probe, Inc., West Chester, PA) to avoid desiccation. The test samples that were almost saturated with CPC-Chem were cured in an airtight container at a high humidity for 28 days at $20^{\circ} \mathrm{C}$. Three types of control samples were prepared: with deionized water only (DW-Cont), with CPC-Chem only (CPC-Cont) and with deionized water and TCP (TCP-Cont).

The UCS of the test samples removed from the mold container after curing was measured with a UCS apparatus T266-31100 (Seikensha Co., Ltd., Japan) at an axial strain rate of $1 \% / \mathrm{min}$. For DW-Cont and TCP-Cont, one test sample was measured by the UCS test. For the other cases, two test samples were examined. The $\mathrm{pH}$ of the test samples was calculated as an average of three measurements (top, bottom and middle of each test sample) using a $\mathrm{pH}$ Spear (Eutech Instruments Pte., Ltd., Singapore). 


\begin{tabular}{|c|c|c|c|c|c|c|}
\hline & \multicolumn{3}{|c|}{ Controls } & \multicolumn{3}{|c|}{ CPC-TCP method } \\
\hline Case name & DW-Cont & CPC-Cont & TCP-Cont & TCP-01 & TCP-05 & TCP-10 \\
\hline \multirow{4}{*}{$\begin{array}{r}\text { Volume of deionized water (light) } \\
\text { or CPC-Chem (bold) }\end{array}$} & $\begin{array}{l}\text { Sand } \\
320.09 \mathrm{~g}\end{array}$ & $\begin{array}{c}\text { Sand } \\
320.09 \mathrm{~g}\end{array}$ & $\begin{array}{c}\text { Sand } \\
288.09 \mathrm{~g}\end{array}$ & $\begin{array}{c}\text { Sand } \\
316.89 \mathrm{~g}\end{array}$ & $\begin{array}{c}\text { Sand } \\
304.09 \mathrm{~g}\end{array}$ & $\begin{array}{c}\text { Sand } \\
288.09 \mathrm{~g}\end{array}$ \\
\hline & $\begin{array}{l}\text { Without } \\
\text { powder }\end{array}$ & $\begin{array}{l}\text { Without } \\
\text { powder }\end{array}$ & $\begin{array}{l}\text { TCP } \\
32.0 \mathrm{~g}\end{array}$ & $\begin{array}{c}+ \\
\mathrm{TCP} \\
3.2 \mathrm{~g}\end{array}$ & $\begin{array}{l}\text { TCP } \\
16.0 \mathrm{~g}\end{array}$ & $\begin{array}{l}\text { TCP } \\
32.0 \mathrm{~g}\end{array}$ \\
\hline & $73.3 \mathrm{~mL}$ & $73.3 \mathrm{~mL}$ & $73.3 \mathrm{~mL}$ & $73.3 \mathrm{~mL}$ & 73.3mL & $73.3 \mathrm{~mL}$ \\
\hline & $\begin{array}{l}\text { Deionized } \\
\text { water }\end{array}$ & CPC-Chem & $\begin{array}{l}\text { Deionized } \\
\text { water }\end{array}$ & CPC-Chem & CPC-Chem & CPC-Chem \\
\hline
\end{tabular}

Fig. 4 Conceptual image of making test samples.

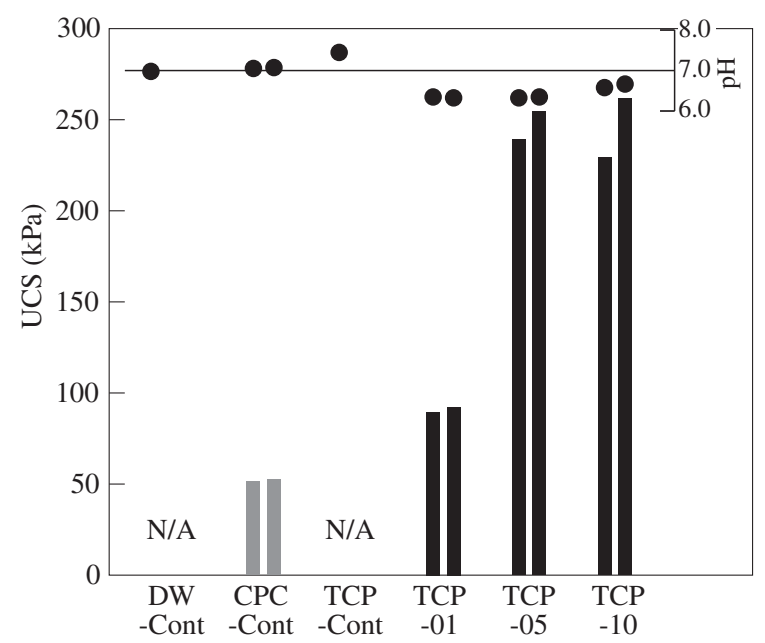

Fig. $5 \mathrm{UCS}$ and $\mathrm{pH}$ of test samples.

Segments of the UCS test samples were observed by scanning electron microscopy (SEM) (SuperScan SS-550, Shimadzu Corporation, Kyoto). The segments of the samples were naturally dried at $20^{\circ} \mathrm{C}$ for a few days and coated with a carbon coater (Quick Carbon Coater SC-701C, Sanyu Electron Co., Ltd., Tokyo). SEM observations were carried out at an accelerating voltage of $15 \mathrm{kV}$ and at a magnification of 2000. Simultaneously, elemental analyses of the test sample segments were carried out by using an energy dispersive X-ray fluorescence spectrometer with SEM.

\section{Results and Discussion}

\subsection{Effect of TCP addition on UCS}

The results for the UCS are shown in Fig. 5. In the figure, "N/A" is an abbreviation for "not available"; the UCS values of DW-Cont and TCP-Cont could not be obtained, because the two samples included no cement materials and fractured owing to their self-weight. This confirmed that TCP possessed no pozzolanic properties, because the UCS of TCP-Cont was unobtainable. The samples with TCP added to CPC-Chem (TCP-01, TCP-05 and TCP-10) exhibited higher UCS values than those of the controls (DW-Cont, CPC-Cont and TCP-Cont). In TCP-05 and TCP-10, the UCS values

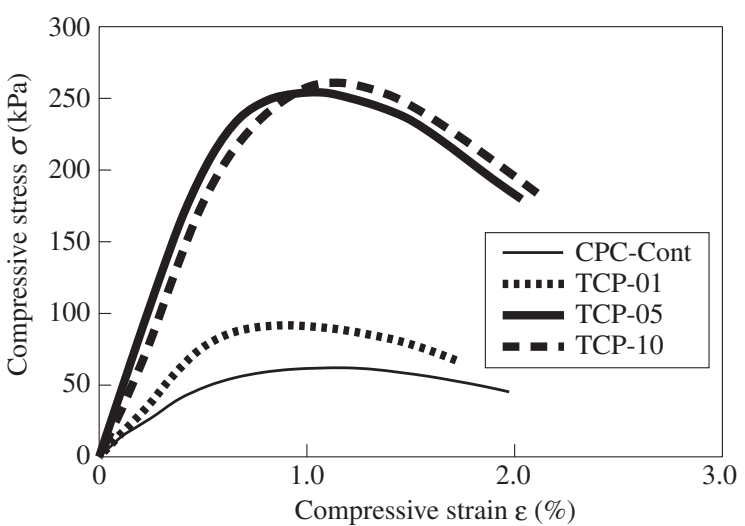

Fig. 6 Stress $(\sigma)$-strain $(\varepsilon)$ curves (only the highest UCS was shown in each case).

exceeded $250 \mathrm{kPa}$, which is five times the UCS of CPC-Cont. These results indicate that the addition of TCP achieved the goal of this study.

The stress $(\sigma)$-strain $(\varepsilon)$ curves of the sample with the largest UCS sample from each test case are shown in Fig. 6. All the stress-strain curves of TCP-added test samples had a distinctive peak at approximately $1 \%$ of the failure strain. Thus, TCP-05 is effectively and economically the optimal composition among the three TCP samples because TCP-05 had a UCS of over $250 \mathrm{kPa}$ and it contained less of the costly material than TCP-10. However, the results are merely limited UCS data obtained after 28 days of curing. The longterm performance of the sand samples, including TCP-05 that is treated with CPC-Chem and TCP, should be proven in the future.

SEM images (Fig. 7) showed that the precipitations of TCP-01 (Fig. 7(e)) and TCP-05 (Fig. 7(f)) had net-like and three-dimensional structures, and the precipitation of TCP-10 (Fig. 7(g)) had a whisker-like structure. For these cases, elemental mappings (Fig. 8) of $\mathrm{Ca}$ and $\mathrm{P}$ had similar distributions with a background of Si (mainly sand particles). These observations suggest that the recognized crystals were classified in CPC. In the report by Akiyama and Kawasaki, ${ }^{11)}$ the test sample that showed the highest UCS value had a whisker-like crystal, consistent with the results of this study. Additionally, the precipitations of TCP-01 and TCP-05 

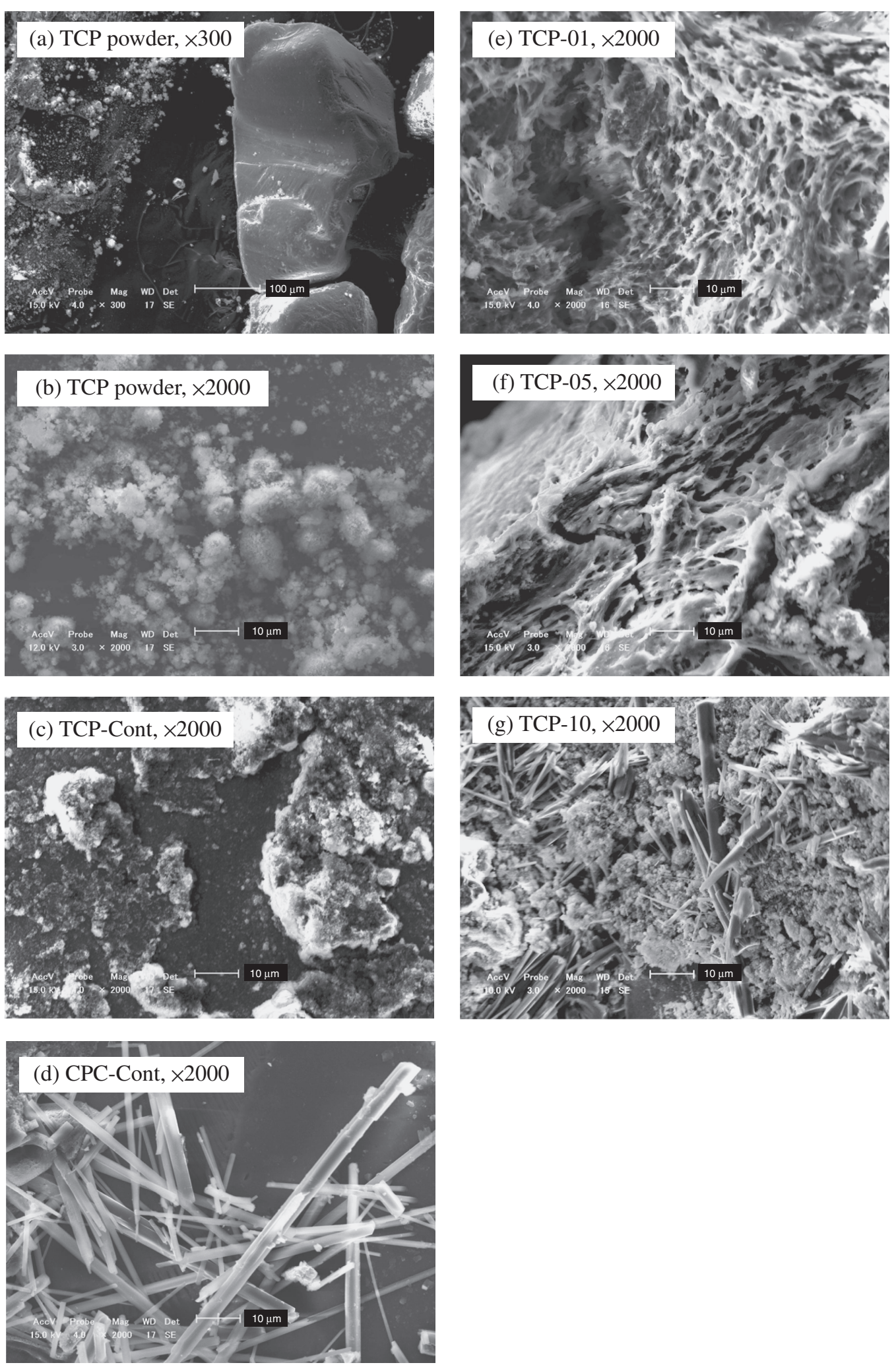

Fig. 7 SEM images of test samples.

grew and developed from whisker-like crystals to a threedimensional structure owing to the coexistence of TCP and CPC-Chem.

The wet density $\rho_{\mathrm{t}}$ of the test samples is shown in Fig. 9. A density increase was expected from the addition of one tenth less TCP powder than sand particles in diameter, which resulted in an improvement of the UCS. By adding both
CPC-Chem and TCP, we established a trend consistent with the hypothesis that the wet density increases with the addition of TCP. The increase in the ratio of the cement material mass to the particles of the base material yielded an increase in the UCS in the test samples. ${ }^{22,23)}$ The weight ratios (\%) of the CPC relative to the entire weight of the test sample were calculated from the volume, wet density, amount of 

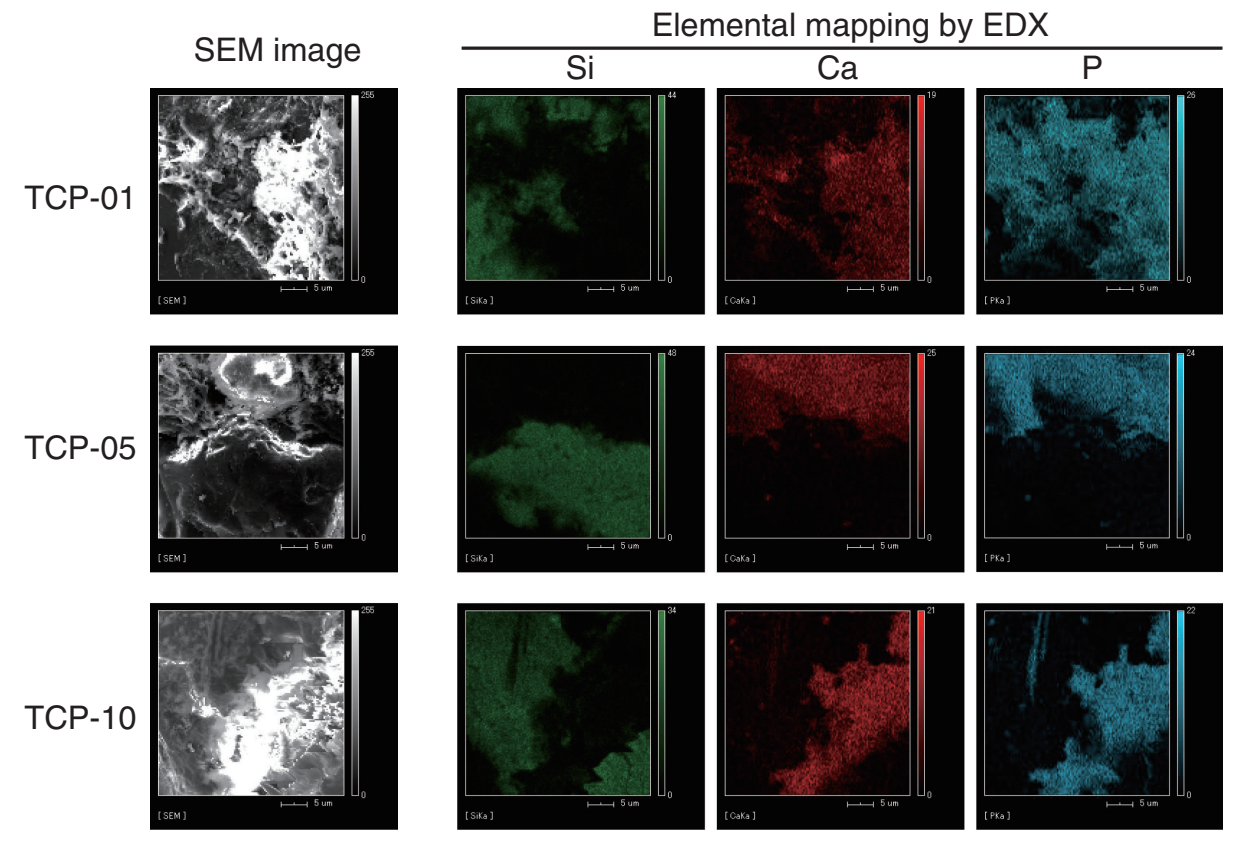

Fig. 8 Elemental mappings of test samples $(\times 2000)$.

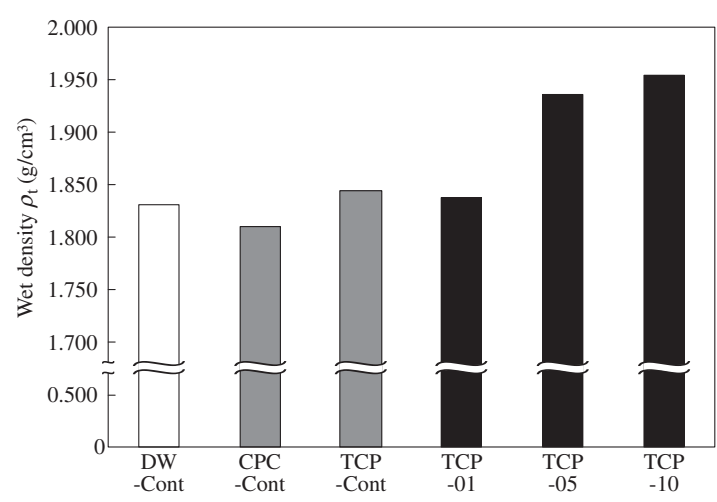

Fig. 9 Wet density of test samples.

additional TCP and theoretical weight (5.5 g, Akiyama and Kawasaki ${ }^{11)}$ ) of the CPC precipitation from the CPC-Chem. The ratios were $2.7 \%$ for TCP-01, $6.6 \%$ for TCP-05 and $11.5 \%$ for TCP-10. The ratios indicate that each application of CPC-Chem or TCP cannot result in a UCS of over $100 \mathrm{kPa}$, but the growth and development of CPC crystals with three-dimensional structures with respect to the increase of cement materials induced an increase in the UCS.

The test samples with added TCP possessed a $\mathrm{pH}$ that was weakly acidic (Fig. 5). Using the $\mathrm{pH}$ dependence of the solubility of CPC (Fig. 3), the CPC-Bio mechanism ${ }^{12)}$ can be available for increasing the $\mathrm{CPC}$ precipitation by a $\mathrm{pH}$ increasing reaction that employs microorganisms and ammonia sources, resulting in a further increase in the UCS. Future studies will report on the effect of the TCP addition with a CPC-Bio cement on the UCS.

\subsection{Prospective use of combination of CPC-Chem and TCP powder}

CPC-Chem has potential as a geotechnical application. ${ }^{11)}$ Stock solutions can be made from fertilizers, and CPCs are a non-toxic, re-excavated mixture of soil, rock and CPC grout.
It is recyclable as an agricultural fertilizer or reusable as a CPC grout. ${ }^{11)}$ On the other hand, cement and cement group hardening materials have the following issues: carbon dioxide is released from the process of cement production, hexavalent chromium can be eluted from cement materials, excessive energy is needed for re-excavating the ground consolidated by cement and the re-excavation material from the cement-consolidated soil and rock is difficult to recycle. The ground improvement method using CPC-Chem as a novel geotechnical technology is anticipated to avoid these recycling and contamination issues.

In this study, the UCS of a sand test sample cemented with CPC-Chem and TCP powder (hereafter called the CPC-TCP method) reached $261.4 \mathrm{kPa}$. Next, we discuss the application prospects based on the merits and the mechanical properties.

The CPC-Chem used in this study has a viscosity similar to grouts with a high concentration of silicate and shows an effective penetrability for soil types ranging from medium sand to fine gravel. ${ }^{11,24)}$ Additionally, the groutability ${ }^{25,26)}(N)$ of the TCP powder $\left(D_{85}=34.8 \mu \mathrm{m}\right)$ with respect to Toyoura sand $\left(D_{15}=150 \mu \mathrm{m}\right)$ was estimated to be $N=\left(D_{15}\right)_{\text {base soil }} /$ $\left(D_{85}\right)_{\text {cement grout }}=4.3$. Although the TCP powder ${ }^{21)}$ used in this study did not satisfy the groutability requirements ${ }^{25}$ ) $(N>25$, sufficiently injected; $N<11$, not sufficiently injected), the CPC-TCP method is expected to be practical if the TCP powder with smaller particles is used for sandy ground with larger particles than those of Toyoura sand.

In addition to its application as a grouting method, the CPC-TCP method can be applied to the sand compaction pile (SCP) method and the deep mixing method that is intended for soft ground. With respect to the SCP method, the ground improvement using the CPC-TCP method can achieve a UCS of $261.4 \mathrm{kPa}$ in comparison to the negligible UCS of sand alone or DW-Cont. Moreover, the CPC-TCP method is practical for reusing the sludge from construction sites as soil materials. A cone index $\left(q_{\mathrm{c}}\right)$ of over $800 \mathrm{kPa}$ is advisable for 
the quality of reusable sludge. ${ }^{27)}$ The relation between $q_{\mathrm{c}}$ and $\mathrm{UCS}$ is generally expressed as $q_{\mathrm{c}}=5-15 \times \mathrm{UCS}$, meaning the minimal requirement of the UCS for reuse of the sludge is approximately $160 \mathrm{kPa}$. Furthermore, $1200 \mathrm{kPa}$ of $q_{\mathrm{c}}$ is needed to allow a dump truck to run stably. ${ }^{28)}$ Because the maximum UCS was $261.4 \mathrm{kPa}$, the estimated $q_{\mathrm{c}}$ was over $1300 \mathrm{kPa}$, which satisfies the demanded quality.

The composition of the CPC-Chem (DAP:CA = $1.5 \mathrm{M}: 0.75 \mathrm{M})$ that induced the maximum UCS in the previous study ${ }^{11)}$ was adopted in this study. The CPC-TCP method can be improved by considering other compositions such as phosphate and calcium stock solutions, and by using the activity of microorganisms. It is thought that a gel-like or amorphous $\mathrm{CPC}$ will precipitate immediately after the mixture of CPC-Chem and sand, according to the concentration of the phosphate stock solution $(1.5 \mathrm{M})$ as shown in Fig. 2, and will temporally self-set toward HA up to 28 days later. To understand the expression mechanism of the UCS resulting from the CPC-TCP method and to use the method more effectively, the temporal relation between the crystal species and the UCS should be investigated in detail. Because other materials besides phosphate can also contribute to the effective use of industrial waste and byproducts of industrial processes, the compatibility between CPC-Chem and other potential materials should be examined.

\section{Conclusions}

For the purpose of improving the performance of $\mathrm{CPC}$ Chem, we observed the effect of the addition of TCP to CPCChem on the UCS for the cementing of test samples. The results confirm that the addition of TCP increases the UCS of the test samples, and these results may apply to CPC-Bio. The main conclusions that can be drawn from this study are as follows:

(1) The UCS of the test samples cemented using the CPCTCP method significantly increased in comparison with that of the non-additive test samples. The UCS reached over $100 \mathrm{kPa}$, the targeted value, with a maximum of $261.4 \mathrm{kPa}$ after 28 days of curing.

(2) The $\mathrm{pH}$ of the test samples cemented using the CPCTCP method was weakly acidic. Considering the $\mathrm{pH}$ dependency on the CPC solubility, the CPC-TCP method can be developed for biogrout by using the $\mathrm{pH}$-increasing activity of microorganisms.

The CPC-TCP method for ground reinforcement is the world's first geotechnical method developed on the basis of knowledge from the interdisciplinary fields of medicine, dentistry, science, agriculture and engineering. Although a number of problems still need to be addressed, the test results obtained in this study indicate that the CPC-TCP method is a promising candidate to improve the UCS of soft ground. As shown in section 4 of this paper, the CPC-TCP method has the potential to be used as a non-contaminating and recyclable application while satisfying the strength requirements.

\section{REFERENCES}

1) S. Kawasaki, A. Murao, N. Hiroyoshi, M. Tsunekawa and K. Kaneko: J. Japan Soc. Engineering Geology 47 (2006) 2-12 (in Japanese with English abstract).

2) V. S. Whiffin, L. A. Van Paassen and M. P. Harkes: Geomicrobiology J. 24 (2007) 417-423.

3) D. A. Den Hamer, A. A. M. Venmans, W. H. Van der Zon and J. J. Olie: Proc. 17th Int. Conf. Soil Mechanics and Geotechnical Engineering, (2009) pp. 2224-2227.

4) W. De Muynck, N. De Belie and W. Verstraete: Ecol. Eng. 36 (2010) $118-136$.

5) J. T. DeJong, B. M. Mortensen, B. C. Martinez and D. C. Nelson: Ecol. Eng. 36 (2010) 197-210.

6) M. P. Harkes, L. A. Van Paassen, J. L. Booster, V. S. Whiffin and M. C. M. Van Loosdrecht: Ecol. Eng. 36 (2010) 112-117.

7) M. Fukue, S. Ono and Y. Sato: Soils Found. 51 (2011) 83-93.

8) A. Al Qabany, K. Soga and C. Santamarina: J. Geotech. Geoenviron. Eng. 138 (2012) 992-1001.

9) J. Chu, V. Stabnikov and V. Ivanov: Geomicrobiol. J. 29 (2012) 544549.

10) L. A. Van Paassen, M. P. Harkes, G. A. Van Zwieten, W. H. Van der Zon, W. R. L. Van der Star and M. C. M. Van Loosdrecht: Proc. 17th Int. Conf. on Soil Mechanics and Geotechnical Engineering, (2009) pp. 2328-2333.

11) M. Akiyama and S. Kawasaki: Eng. Geol. 125 (2012) 119-128.

12) M. Akiyama and S. Kawasaki: Eng. Geol. 137-138 (2012) 29-39.

13) H. Yamazaki, K. Maeda, K. Takahashi, K. Zen and K. Hayashi: Technical Note of Port and Harbour Research Institute 905 (1998) 1-29 (in Japanese).

14) L. C. Chow: The Centennial Memorial Issue of the Ceramic Society of Japan 99 (1991) 954-964.

15) G. H. Nancollas and J. S. Wefel: J. Dent. Res. 55 (1976) 617-624.

16) J. F. De Rooij, J. C. Heughebaert and G. H. Nancollas: J. Colloid Interface Sci. 100 (1984) 350-358.

17) L. Changsheng and W. Shen: J. Mater. Sci. Mater. Med. 8 (1997) 803807.

18) K. Moriyama, T. Kojima, Y. Minawa, S. Matsumoto and K. Nakamachi: Environ. Technol. 22 (2001) 1245-1252.

19) H. Miyazaki, N. Adachi and T. Ota: Annual Report of the Ceramics Research Laboratory Nagoya Institute of Technology 8 (2008) 13-16 (in Japanese with English abstract)

20) M. S. Tung: Calcium Phosphates in Biological and Industrial Systems, ed. by A. Zahid, (Kluwer Academic Publishers, Norwell, 1998) pp. 119.

21) Wako Pure Chemical Industries, Ltd.: Wako Chemicals, 36th Edition (2010).

22) A. Kobayashi and F. Tatsuoka: Seisan Kenkyu 34 (1982) 304-307 (in Japanese).

23) N. Molenaar and A. A. M. Venmans: Eng. Geol. 35 (1993) 103-122.

24) R. H. Karol: Chemical Grouting and Soil Stabilization, 3rd Ed., (CRC Press, Boca Raton, FL, 2003).

25) S. Akbulut and A. Saglamer: Tunn. Undergr. Space Technol. 17 (2002) 371-380.

26) E. Tekin and S. O. Akbas: Bull. Eng. Geol. Environ. 70 (2011) 153161.

27) Japanese Geotechnical Society: Doshitsushiken no Houhou to Kaisetsu, (Japanese Geotechnical Society, Tokyo, 2000).

28) Public Works Research Institute: Kensetsuodei Saisei Riyou Manual, (Taisei Publishing Co., Ltd., Tokyo, 2008). 